\begin{tabular}{|l|l|l||}
\hline \multicolumn{2}{|c|}{ PublisherInfo } \\
\hline \hline PublisherName & $:$ & BioMed Central \\
\hline \hline PublisherLocation & $:$ & London \\
\hline \hline PublisherImprintName & $:$ & BioMed Central \\
\hline \hline
\end{tabular}

\title{
Coiled interactions
}

\begin{tabular}{||l|l|l||}
\hline \multicolumn{2}{|c|}{ ArticleInfo } \\
\hline \hline ArticleID & $:$ & 3841 \\
\hline \hline ArticleDOI & $:$ & $10.1186 /$ gb-spotlight-20001123-02 \\
\hline \hline ArticleCitationID & $:$ & spotlight-20001123-02 \\
\hline \hline ArticleSequenceNumber & $:$ & 278 \\
\hline \hline ArticleCategory & $:$ & Research news \\
\hline \hline ArticleFirstPage & $:$ & 1 \\
\hline \hline ArticleLastPage & $:$ & 2 \\
\hline \hline & & RegistrationDate : 2000-11-23 \\
ArticleHistory & $:$ & OnlineDate $\quad$ 2000-11-23 \\
\hline \hline ArticleCopyright & $:$ & BioMed Central Ltd2000 \\
\hline \hline ArticleGrants & $:$ & \\
\hline \hline ArticleContext & $:$ & 130591111 \\
\hline \hline
\end{tabular}


William Wells

Email:wells@biotext.com

Two-hybrid assaysare great for detecting protein-protein interactions, but they scale as the square of the number of candidate interactions. Screening every possible interaction in yeast would require examining approximately $3.6 \times 107$ pairs, which is why previous large-scale screens byUetz et al. and Ito et al. have pooled libraries of constructs. In the November 21 Proceedings of the National Academy of Sciences, Newman et al. find that such approaches can miss a great number of valid interactions (Proc Natl Acad Sci USA 2000, 97:13203-13208). Newman et al. approach the problem by first screening the yeast genome sequence computationally for the coiled-coil interaction motif, which consists of two or more helices that wrap around each other. They then analyze 162 coiled-coil sequences, selected on the basis of either their high predicted coil scores or their association with mitotic processes, and use two hybrid assays to find 213 unique interactions. The results reveal an extraordinary web of interactions at the yeast spindle pole body, and an unexpected connection between spindle pole and kinetochore proteins.

\section{References}

1. A novel genetic system to detect protein-protein interactions.

2. A comprehensive analysis of protein-protein interactions in Saccharomyces cerevisiae.

3. Toward a protein-protein interaction map of the budding yeast: A comprehensive system to examine two-hybrid interactions in all possible combinations between the yeast proteins.

\section{Proceedings of the National Academy of Sciences, [http://www.pnas.org/]}

5. MultiCoil: a program for predicting two- and three-stranded coiled coils.

6. The yeast proteome database (YPD) and Caenorhabditis elegans proteome database (WormPD): comprehensive resources for the organization and comparison of model organism protein information.

This PDF file was created after publication. 